CENTRO, No. 2, No. 1, 1985, pp. 21-34.

(c) University of Malta Press.

\title{
Prerequisites for the Development of Mass Balance Models of the Biogeochemical Cycle of Mercury in the Mediterranean Sea
}

\author{
MOHSEN M. OSMAN
}

Oceanography Department, Faculty of Science, Alexandria University, Moharam Bey, Alexandria,

Egypt.

(Received 30th September, 1985)

\begin{abstract}
The information presently available on the biogeochemical cycle of mercury in the Mediterranean Sea is reviewed in an attempt to evaluate our state of knowledge, to pinpoint gaps in our understanding and to assess the possibility of establishing mass balance models.

The need to promote such models for either the large scale Mediterranean system or individual small scale coastal basins have been discussed. The basic requirements to facilitate the development of mass balance models for both scales were identified.
\end{abstract}

\section{Introduction}

The last decades have seen an increased awareness of the fate and pathways of mercury in the marine environment because of its significance with regard to human health. For the Mediterranean Sea, this problem should attain much more importance due to the following reasons:-

- The semi-closed nature of the sea, together with its particular topography and peculiar marine meteorological conditions, leading to accumulation and amplification of contamination effects (Osterberg \& Keckes, 1977).

- the unique richness of the Mediterranean basin in mercury deposits. Metallic mercury and deposits of cinnabar occur in Algeria, Italy, Spain, Turkey and 
Yugoslavia (UNEP, 1983a). It is worth mentioning that the active mining sites in the Mediterranean account for about $50 \%$ of the world's production (Gavis \& Ferguson, 1972; Renzoni et al. 1978).

- Mercury levels in the tissues of anchovy, mackerel, sardine and tuna fish of the Mediterranean Sea are about twice the mercury concentrations contained in the North Atlantic specimens of similar size. Because these are open sea pelagic fishes, many investigators (Bernard, 1978; Cumont et al., 1972; Renzoni et al., 1978) believe that the high mercury levels are not principally derived from man's activity (anthropogenic sources), but must be accepted as a natural phenomenon due to a Mediterranean mercury anomaly.

It is to be mentioned that the last statement-hypothesis is a controversial subject. A final confirmation of its validity depends upon a comprehensive knowledge of mercury biogeochemistry in the Mediterranean Sea.

In fact, the assessment of the present impact of mercury on the Mediterranean Sea environment, the identification of primary sites of mercury accumulation, the determination of systems' waste receiving capacity and the analysis and prediction of future trends are practically impossible without an adequate model of the biogeochemical cycling of mercury. In this respect, mass balance models, which provide a dynamic description of mercury distribution and flow through the marine environment, are the most appropriate approach. Furthermore, such models are regarded as an integral part of the monitoring and research activities of UNEP MED POL-PHASE II PROGRAMME. It is enough, in this context, to mention that an objective of the research activity " $\mathrm{K}$ ", concerned with the biogeochemical cycle of specific pollutants (including mercury), is "... to allow for detailed mass balance computations." (UNEP, 1983b).

The scope of the present work is to:-

a. assess the present state of knowledge on the biogeochemical cycle of mercury in the Mediterranean Sea, and to pinpoint gaps in our understanding;

b. discuss the existing data bases available for the Mediterranean Sea and define the basic conditions determining the direction of future research and monitoring strategy in response to actual demands; and

c. to identify the requirements for facilitating mass balance model developments for the Mediterranean Sea.

\section{Mass balance models - the scale problem}

The pattern of mercury flow in the marine ecosystem, schematically represented in Fig. 1, is well known and accepted. However, knowledgable assessment of the biogeochemical cycle can be achieved only on the basis of an approach which relates quantitatively the source functions, reservoir concentrations and fluxes between reservoirs and sinks. In this respect, mass balance models represent an ideal tool.

The basic requirements for the establishment of mass balance models are the quantification of mercury fluxes through the interfacial boundaries of the system i.e. the input/output functions to/from the system via rivers, atmosphere, sediments and adjacent seas. In addition, it is essential to estimate precisely not only the concentrations and chemical forms of mercury in the different compartments of the marine system, i.e. sea water, sediments and marine biota, but also its flow between the ambient and the organisms at various levels within the trophic network. 


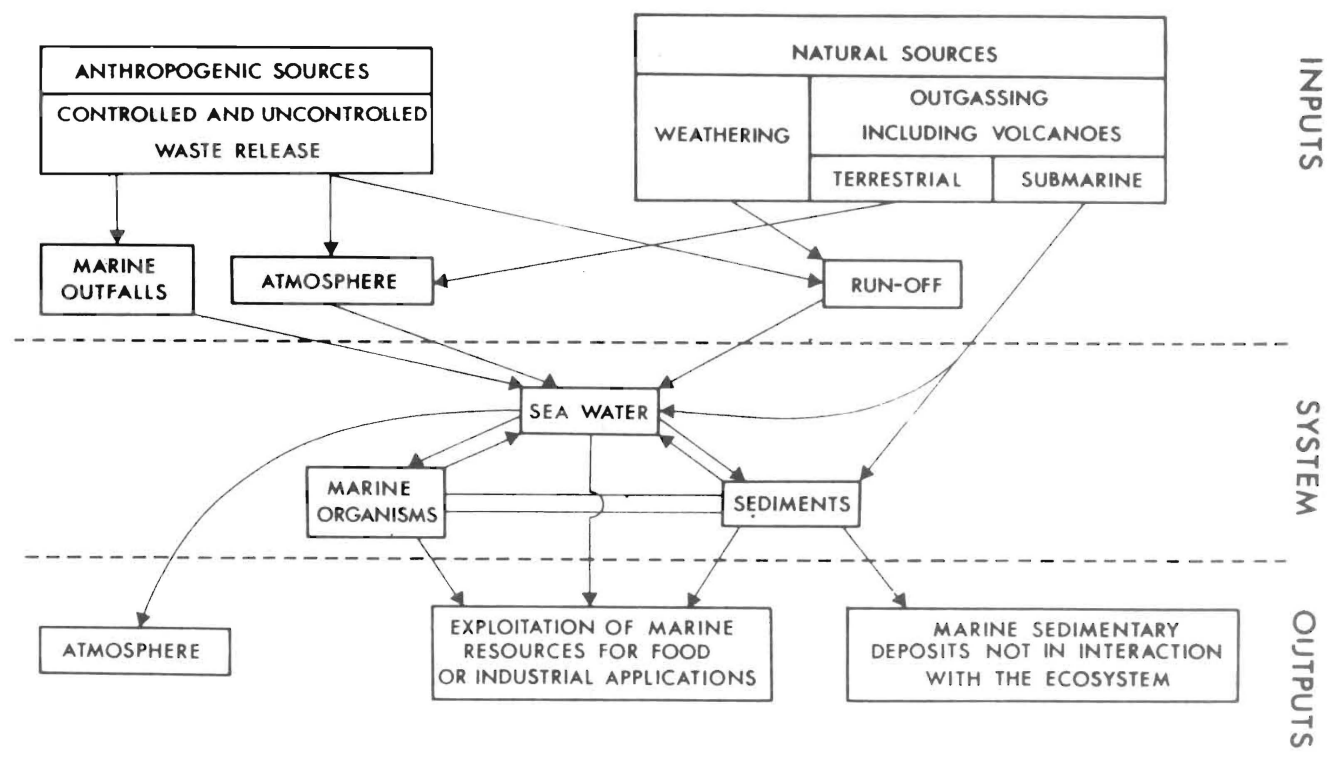

Fig. 1 Generalized scheme of inputs and fates of mercury in the marine ecosystem.

In the context of previous remarks regarding the special nature of the Mediterranean, it appears that our concern should not be limited to pollution dangers of mercury at areas of high level localized discharges (hot spots), but must include the Mediterranean Basin as a whole. In fact, any changes in the characteristics of the marine ecosystem provided by small, slow but continuing increases of mercury concentrations may be an early warning sign or indicator of deleterious effects.

However, it is necessary to distinguish between the large scale Mediterranean Sea system and individual small scale coastal systems. Significant variations exist between the two systems with regard to the various parameters and processes which characterize each of them (levels of mercury, residence times ...etc). From the modelling point of view, the differences in the dimensional scales, physical and temporal boundaries adapted for each system, in addition to the data base, required to assist mass balance calculations and to provide inputs for model formulation, imply the distinction between both systems. In fact, the consideration of the above-mentioned differences between the large scale Mediterranean Sea system and small scale coastal systems has a very high priority from the initial setting of an effective surveillance monitoring programme to the validation of the model.

Efficient mass balance models for both scales are actually needed to evaluate short and long term variations, near-in and far-away effects of mercury in the marine environment. They are required to assist in ocean and coastal zone managements, decision making and for the implementation of the Barcelona Convention. Furthermore, they are of great importance for the development of sound strategies for the conservation of the Mediterranean marine environment including the control and abatement of pollutants.

\section{The entire Mediterranean Basin system}

In this part we shall discuss the information that is available on the biogeochemical cycle of mercury in the Mediterranean sea, in an attempt to evaluate our present status 
of knowledge and to identify the needed requirements for the development of mass balance models for the whole Mediterranean.

The mercury load from land-based sources, including rivers, domestic and industrial discharges, have been assessed through the MED POL X JOINT PROJECT (UNEP, 1979). However, this was based, to a great extent, on indirect methods. Insufficient data were used for estimating industrial mercury discharges. Obviously all these shortcomings were reflected in the obtained results (Table 1 ; Fig. 2). The given values may be considered accurate within an error range of about one order of magnitude (UNEP, 1984). Table 1 shows that discharges of mercury are largely due to river inputs with only $6 \%$ from other land-based sources. Inputs from underground seepage and the innumerable geothermal springs were not considered at all. Summing up, the existing information on the quantity and characteristics of mercury loads entering the Mediterranean Sea through land-based sources is by no means satisfactory and will clearly need to be augmented substantially.

Information on mercury levels in the lower atmosphere over the Mediterranean Sea as well as atmospheric mercury inputs to the sea are very scanty. According to Ferrara et al. (1982) the total mercury concentration in the Mediterranean atmosphere ranges from 2 to $4 \mathrm{ngm}^{-3}$. Analysis of several atmospheric samples collected over the Tyrrhenian Sea, Sicily Strait and Ionian Sea during the ETNA 80 Cruise of September 1980 (Chesselet et al., 1981) and over the Western Mediterranean during April 1981 by the PHYCEMED 81 Cruise (Arnold et al., 1982) showed that the mean atmospheric concentrations of mercury were 0.10 and $0.24 \mathrm{ngm}^{-3}$ respectively. It is apparent that both values are higher than the mean mercury level in the atmosphere over the North Atlantic (0.065 ngm $\left.{ }^{-3}\right)$ given by Buat-Menard and Chesselet (1979). From

Table 1. Sources and inputs of mercury in the Mediterranean

\begin{tabular}{|c|c|c|c|c|c|c|c|}
\hline \multirow[t]{3}{*}{ Region } & \multicolumn{4}{|c|}{ Originating in coastal zone } & \multirow{2}{*}{\multicolumn{2}{|c|}{$\begin{array}{l}\text { Carried by } \\
\text { rivers }\end{array}$}} & \multirow{3}{*}{$\begin{array}{r}\text { Total } \\
t / a\end{array}$} \\
\hline & \multicolumn{2}{|c|}{ Domestic } & \multicolumn{2}{|c|}{ Industrial } & & & \\
\hline & $t / a$ & $\%$ & $t / a$ & $\%$ & $\mathrm{t} / \mathrm{a}$ & $\%$ & \\
\hline $\mathrm{I}$ & 0.04 & 2 & 0.60 & 24 & 1.8 & 74 & 2.5 \\
\hline II & 0.28 & 1 & 2.7 & 8 & 30 & 91 & 33 \\
\hline III & 0.04 & 1 & 0.20 & 7 & 2.5 & 92 & 2.7 \\
\hline IV & 0.12 & 1 & 1.1 & 10 & 9.5 & 89 & 10.7 \\
\hline V & 0.084 & 0 Appr. & 0.540 & 1 & 40 & 99 & 41 \\
\hline VI & 0.026 & 0 Appr. & 0.16 & 2 & 9.6 & 98 & 9.8 \\
\hline VII & 0.032 & 2 & 0.16 & 9 & 1.5 & 88 & 1.7 \\
\hline VIII & 0.054 & 0 Appr. & 0.22 & 2 & 14 & 98 & 14.3 \\
\hline IX & 0.01 & 0 Appr. & 0.05 & 1 & 7 & 99 & 7.1 \\
\hline $\mathrm{X}$ & 0.074 & 1 & 1.2 & 17 & 5.6 & 82 & 6.9 \\
\hline Total & 0.76 & 0.6 & 6.9 & 5.4 & $122^{*}$ & 94 & 129.7 \\
\hline \multicolumn{8}{|c|}{$\begin{array}{l}\text { * Of this figure, } 32 \text { tons are considered as "background" } \\
\text { (UNEP, 1979) }\end{array}$} \\
\hline
\end{tabular}




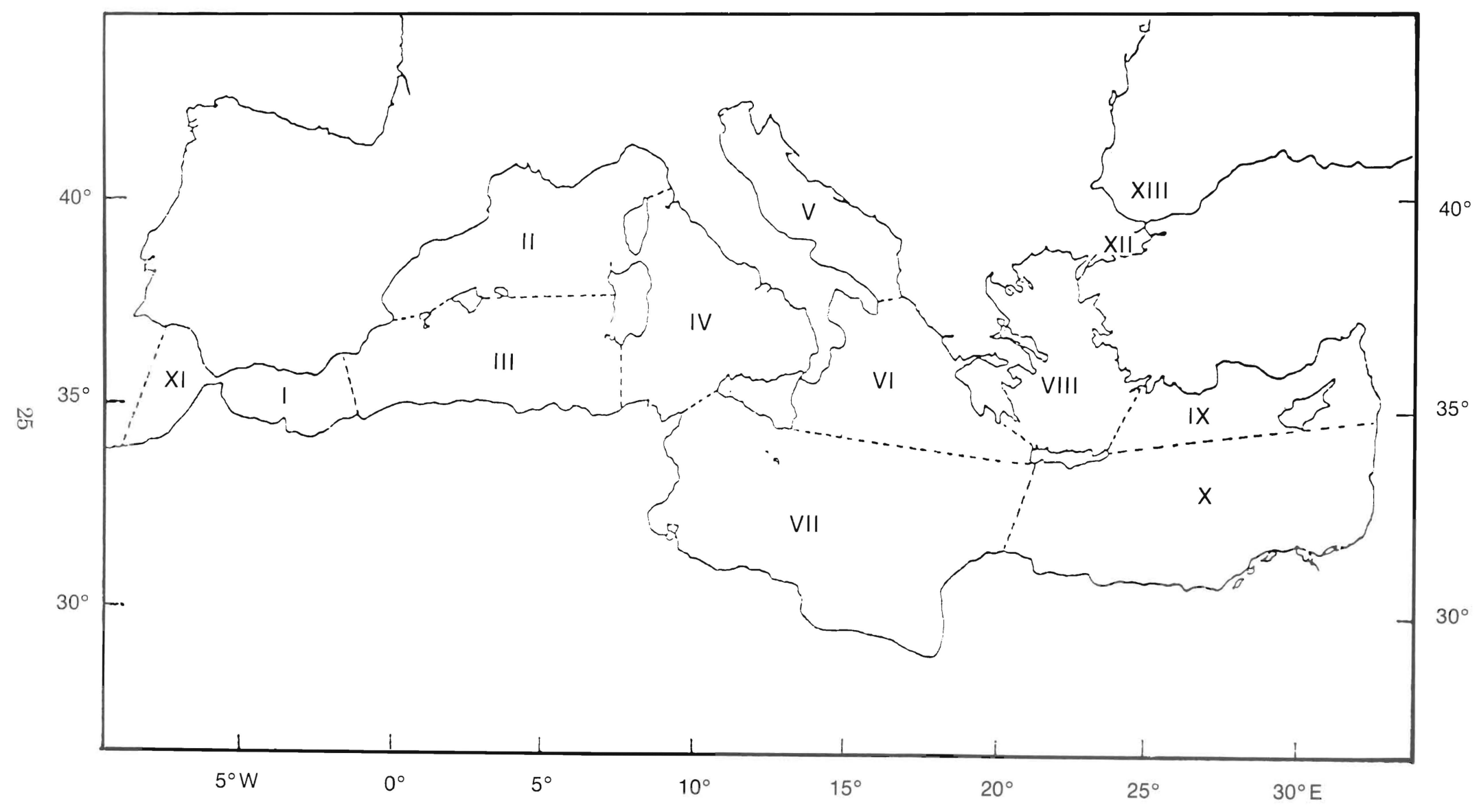

Fig. 2 Regional divisons of the Mediterranean Sea in Pilot Project MED POL II 
measurements carried out during the PHYCEMED 81 Cruise in the Western Basin of the Mediterranean Sea, Arnold et al., (1982) estimated an annual deposition rate of mercury of about $50 \mathrm{~g} \mathrm{~km}^{-2}$. It is believed that the mercury atmospheric flux is affected by the transport of man-made aerosols mainly from the industrial regions of Western Europe (Arnold et al., 1982) and by volcanic activity (Buat-Menard and Arnold, 1978). In spite of the lack of an accurate figure which accounts for the total amount of mercury carried by atmospheric fallout (dry and wet) to the entire Mediterranean Sea, the significance of this source with regard to other inputs can be roughly evaluated. If the value of the deposition rate of mercury given by Arnold et al., (1982) is extrapolated to the total area of the Mediterranean Sea $-2.5 \times 10^{6} \mathrm{~km}^{2}$ (Bethoux, 1980) - this would give a mercury input of $125 \mathrm{t} \mathrm{yr}^{-1}$. This figure, however, suggests that the atmosphere is an important source of mercury for the whole Mediterranean Sea, and has about the same

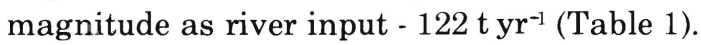

Table 2. Mercury concentrations in open waters of the Mediterranean Sea

\begin{tabular}{|c|c|c|}
\hline Region & $\begin{array}{l}\text { Physico-chemical } \\
\text { form }\end{array}$ & $\begin{array}{c}\text { Concentration } \\
\mu \mathrm{g} / \mathrm{l}\end{array}$ \\
\hline I & Total & $\begin{array}{l}0.11 \\
(0.062-0.17)\end{array}$ \\
\hline \multirow[t]{2}{*}{ II } & Particulate & 0.0013 \\
\hline & Dissolved & $\begin{array}{l}0.020 \\
(0.008-0.032)\end{array}$ \\
\hline III & Dissolved & $\begin{array}{l}0.014 \\
(0.005-0.30)\end{array}$ \\
\hline IV & Dissolved & $\begin{array}{l}0.026 \\
(0.010-0.040)\end{array}$ \\
\hline VI-VII & Dissolved & $\begin{array}{l}0.030 \\
(0.005-0.080)\end{array}$ \\
\hline VIII & Dissolved & $\begin{array}{l}0.040 \\
(0.015-0.080)\end{array}$ \\
\hline $\mathrm{X}$ & Dissolved & $\begin{array}{l}0.016 \\
(0.012-0.020)\end{array}$ \\
\hline & Total & $\begin{array}{l}0.12 \\
(0.09-0.14)\end{array}$ \\
\hline
\end{tabular}

(UNEP, 1983a)

Note: see also Figure 2. 
Another aspect to be considered in mercury budget calculations is the assessment of the net flux of mercury due to water exchange with the adjacent seas, i.e. Atlantic Ocean and Black Sea. Due to the lack of data indispensable for this purpose, it is impossible, at the moment, to evaluate accurately the net mercury transport through the Straits of Gibraltar and Dardanelles. However, assuming a difference of only $1 \mathrm{ngl}^{-1}$ in mercury concentrations between the inflowing Atlantic and the outflowing Mediterranean waters (53.0 and $50.5 \times 10^{12} \mathrm{~m}^{3} \mathrm{yr}^{-1}$ respectively. Bethoux, 1980) we get an input/output of about $50 \mathrm{t} \mathrm{yr}^{-1}$ of mercury - an amount which cannot be neglected.

The existing information on the levels and chemical forms of mercury in the different compartments of the Mediterranean marine ecosystem were recently reported by UNEP (1983a). Mercury concentrations in the open Mediterranean water (Table 2) indicate that the dissolved component ranges between 0.005 and $0.08 \mu \mathrm{g} \mathrm{l}^{-1}$, the particulate around $0.0013 \mu \mathrm{g} \mathrm{l}^{-1}$, and the total ranges from 0.09 to $0.14 \mu \mathrm{g} \mathrm{l}^{-1}$.

Representative data for mercury levels in deep sea Mediterranean sediments are lacking. Most of the results on mercury content, summarized in Table 3, characterize actually coastal areas. Consequently they may reflect natural and anthropogenic mercury levels related to localized conditions. Only the values $\left(0.07-0.97 \mu \mathrm{g} \mathrm{g}^{-1} \mathrm{dry}\right.$ weight) reported for the Adriatic Sea (Table 3, region V) can be taken to represent, more or less, open sea conditions, since they are mostly for water depths greater than $1000 \mathrm{~m}$.

A considerable amount of data on mercury levels in Mediterranean marine biota has been reported (UNEP, 1983a), as a result of the MED POL Projects on monitoring of mercury in marine organisms. Concentrations of mercury in 18 species of fish and 3 species of molluscs and crustaceans are illustrated in Table 4. The highest mean mercury concentrations were found in tuna and certain other pelagic fishes. The high levels reported for the 2 benthic fishes Mullus barbatus and Upeneus moluccensis are probably not representative for the whole Mediterranean Sea. According to the same report (UNEP, 1983a), almost half of the Mullus barbatus samples were collected from coastal zones close to the mercury geochemical anomaly area of Monte Amiato (Italy), while Upeneus moluccensis was sampled only from the Eastern Mediterranean. It is relevant to note that analytical data for mercury content of fish muscle sampled in various seas (Table 5) indicate that fishes of the Mediterranean Sea have, generally, higher mercury levels than those from the Atlantic, Pacific and Indian Oceans.

The mean concentrations of mercury, together with the variation ranges in some Mediterranean molluscs and crustaceans are given in Table 4. However the given averages seem to be misleading, since they were based on unrepresentative data for the Mediterranean Sea as a whole. It should be kept in mind that the use of "average" Mediterranean data, which is based on figures representing localized conditions, incomplete geographical coverage and uneven regional distributions throughout the sea, carries a grave risk.

It is to be mentioned that the data compiled through the MED POL projects on mercury monitoring was restricted to the determination of its levels mainly in the marine organisms without inclusion of the other compartments, principally sea water and sediments. With the accuracy and paucity of the available information it is hard to confirm whether mercury levels in the Mediterranean open waters and deep sea sediments are significantly higher than those of other oceans. Furthermore, there is a severe lack of data on the different physico-chemical forms of mercury (dissolved and particulate, methylated and inorganic) present in the Mediterranean marine ecosystem. Even if increasing data are gathered on the distribution of mercury among the various compartments, a serious lack of knowledge still prevails on the flow and 
Table 3. Mercury concentrations in sediments of the Mediterranean Sea.

\begin{tabular}{|c|c|c|c|}
\hline & Region & $\begin{array}{l}\text { Extraction } \\
\text { method }\end{array}$ & $\begin{array}{l}\text { Concentration } \\
\mu \mathrm{g} / \mathrm{g} \text { dry weight }\end{array}$ \\
\hline I & Alboran Sea & Total & 0.26 (mean) \\
\hline \multirow[t]{6}{*}{ II } & Liguri.ın coasts & $\mathrm{HNO}_{3}, \mathrm{HCl}$ & $0.16-5.4$ \\
\hline & Ebro delta & conc. $\mathrm{HNO}_{3}$ & $0.065-1.1$ \\
\hline & Area of Marseille & $\mathrm{HNO}_{3}$ & $0.07-21$ \\
\hline & Bay of Cannes & $\begin{array}{l}\mathrm{HNO}_{3}, \mathrm{HPO}_{4} \\
\text { fraction } 63 \mu\end{array}$ & $0.1-0.4$ \\
\hline & Gulf of Nice & $\mathrm{HNO}_{3}, \mathrm{HClO}_{4}$ & $0.01-0.16$ \\
\hline & Catalan coasts & conc. $\mathrm{HNO}_{3}$ & $0.2-1.0$ \\
\hline III & $\begin{array}{l}\text { Santa Gilla } \\
\text { lagoon, Cagliari }\end{array}$ & $\mathrm{H}_{2} \mathrm{SO}_{4}, \mathrm{HNO}_{3}$ & $0.7-37$ \\
\hline \multirow[t]{5}{*}{ IV } & Tyrrhenian Sea & - & $0.05-0.24$ \\
\hline & Tuscany Coast & - & \\
\hline & near Solvay plant & & $1.1-1.3$ \\
\hline & $4 \mathrm{~km} \mathrm{~S}$ and $\mathrm{N}$ & & $0.1-0.8$ \\
\hline & $10 \mathrm{~km} \mathrm{~S}$ and $\mathrm{N}$ & & $0.04-0.1$ \\
\hline \multirow[t]{6}{*}{ V } & Gulf of Trieste & - & $1.4-14.8$ \\
\hline & $\begin{array}{l}\text { (close to cinnabar } \\
\text { mine) }\end{array}$ & & 19.4 \\
\hline & Gulf of Venice & $\mathrm{H}_{2} \mathrm{SO}_{4}$ & $0.15-3.0$ \\
\hline & Kastela Bay & Total & 8.5 \\
\hline & $\begin{array}{l}\text { Dalmatia } \\
\text { (chlor-alkali plant) }\end{array}$ & & \\
\hline & Adriatic Sea & Total & $0.07-0.97$ \\
\hline \multirow[t]{4}{*}{ VIII } & Evoikos Gulf & $0.5 \mathrm{HCl}$ & $0.3-0.8$ \\
\hline & Aegean Sea & fraction $55 \mu$ & \\
\hline & $\begin{array}{l}\text { Saronikos Gulf, } \\
\text { Athens }\end{array}$ & Total & $0.5-1$ \\
\hline & Athens outfall & Total & $0.5-3$ \\
\hline IX & Coasts of Turkey & $\mathrm{HNO}_{3}$ & $0.019-0.48$ \\
\hline \multirow[t]{4}{*}{$\mathrm{X}$} & Region of Alexandria & conc. $\mathrm{HNO}_{3}$ & 0.8 \\
\hline & $\begin{array}{l}\text { plant) } \\
\text { plose to chior-alkail }\end{array}$ & & $9-15$ \\
\hline & Haifa Bay & $\begin{array}{l}\mathrm{HNO}_{3} \\
\text { fraction } 250 \mu\end{array}$ & $0.008-0.73$ \\
\hline & Hanigra to Hafifa & & $0.01-0.57$ \\
\hline
\end{tabular}

(UNEP, 1983a)

Note: see also Figure 2. 
Table 4. Mercury concentrations in Mediterranean fish $(\mu \mathrm{g} / \mathrm{kg}$ wet weight)

\begin{tabular}{lrrrrr}
\hline \multicolumn{1}{c}{ Species } & $\begin{array}{c}\text { Number of } \\
\text { Samples }\end{array}$ & Minimum & Maximum & Mean & $\begin{array}{r}\text { Standard } \\
\text { Deviation }\end{array}$ \\
\hline Boops boops & 15 & 20 & 432 & 125 & 104 \\
Dentex gibbosus & 12 & 99 & 178 & 135 & 19 \\
Engraulis encrasicolus & 254 & 20 & 580 & 167 & 85 \\
Merluccius merluccius & 16 & 31 & 258 & 131 & 77 \\
Mugil auratus & 39 & 1 & 5600 & 171 & 880 \\
Mullus barbatus & 1265 & 2 & 7900 & 694 & 760 \\
Mullus surmuletus & 234 & 0 & 510 & 91 & 57 \\
Pagellus acarne & 12 & 30 & 337 & 159 & 92 \\
Pagellus erythrinus & 112 & 53 & 805 & 203 & 115 \\
Sarda sarda & 11 & 290 & 2300 & 1150 & 644 \\
Sardinella aurita & 47 & 120 & 390 & 248 & 70 \\
Saurida undosquamis & 143 & 42 & 649 & 137 & 93 \\
Scomber scombrus & 16 & 125 & 510 & 335 & 122 \\
Solea vulgaris & 10 & 10 & 220 & 71 & 65 \\
Thunnus alalunga & 38 & 60 & 399 & 262 & 76 \\
Thunnus thynnus thynnus & 325 & 20 & 6300 & 1050 & 760 \\
Thrachurus mediterraneus & 54 & 8 & 955 & 116 & 160 \\
Upeneus moluccensis & 127 & 38 & 1112 & 426 & 290 \\
& & & & & \\
\hline
\end{tabular}

Mercury concentrations in Mediterranean molluscs ( $\mu \mathrm{g} / \mathrm{kg}$ wet weight)

\begin{tabular}{lrrrrr} 
Donax trunculus & 42 & 35 & 909 & 210 & 220 \\
Mytilus galloprovincialis & 488 & 4 & 7000 & 232 & 596 \\
Perna perna & 192 & 20 & 370 & 76 & 50 \\
& & & & & \\
\hline
\end{tabular}

Mercury concentrations in Mediterranean crustaceans $(\mu \mathrm{g} / \mathrm{kg}$ wet weight)

\begin{tabular}{lrrrrr} 
Nephrops norvegicus & 554 & 59 & 3000 & 917 & 494 \\
Parapanaeus longirostris & 39 & 110 & 1195 & 345 & 233 \\
Squilla mantis & 20 & 65 & 455 & 152 & 86 \\
\hline
\end{tabular}

(UNEP, 1983a)

transformation of mercury through the marine ecosystem as well as on its outputs through the interfaces (re-emission from sea water to the atmosphere, sedimentation etc.). In fact, measurements of mercury levels should not be the goal of the research efforts, but must be regarded as a tool in quantifying the biogeochemical processes.

From the above review it is quite evident that the existing data base for the Mediterranean Sea is scarce and fragmentary, and cannot provide a good basis for a final assessment of mercury cycling. Our present knowledge (theory, available laboratory and field data) on the hydrodynamics, biogeochemistry and ecology of the sea is limited to qualitative, rather than quantitative, information and is insufficient to formulate a mass balance model which simulates the cycling of mercury on the scale of the entire Mediterranean Sea. Moreover, attempts to generate such a quantitative large scale model seem to be technically unfeasible even in the near future. Unfortunately, 
the data base intrinsic to delving into the problem is hindered by the international, expensive and extensive nature of the required sampling efforts.

On the contrary, small scale mass balance models of well defined coastal systems are within the present capabilities of many Mediterranean countries. Besides their importance for the assessment of the pollution dangers of mercury, these models may constitute essential first step towards the construction of larger regional models (Eastern or Western Mediterranean). Obviously, a regional model is nothing else but a sub-model of a large scale one.

In fact the urgent need for the development of small scale mass balance models concerning mercury cycling in coastal systems of the Mediterranean Sea is self evident. However, it seems beneficial, with the above mentioned conditions in mind, to provide an integrated exposure to the available knowledge on mercury cycling in different Mediterranean coastal systems and to identify the research requirements necessary to facilitate the present and foreseeable developments in modelling efforts.

\section{Coastal systems}

Because of its peculiar position at the land-sea boundary, the coastal zone often receive contributions of nutrients, heavy metals and other pollutants, mainly from land-based sources, that are many orders of magnitude higher per unit area than any other area of the sea. With regard to mercury in different coastal areas of the Mediterranean Sea, various studies (UNEP, 1983a) indicated that in certain localized basins, terrestrial discharges do result in "hot spots". Generally speaking, variations in the levels and chemical forms of mercury were found to be largely dependent on, and markedly related to the quantity and quality of the discharged mercury loads.

Table 5. Range of approximate mean concentrations of mercury (expressed in $\mathrm{mg} / \mathrm{kg}$ wet weight) recorded in muscle tissue of various marine species (modified after Piotrowski \& Inskip, 1981)

\begin{tabular}{|c|c|c|c|c|}
\hline \multirow{2}{*}{ Fish Species } & \multicolumn{4}{|c|}{ Ocean/Sea } \\
\hline & Atlantic & Pacific & Indian & Mediterranean \\
\hline Mackerel & $0.07-0.20$ & $0.16-0.25$ & 0.005 & 0.335 \\
\hline Sardine & $0.03-0.06$ & 0.03 & 0.006 & 0.248 \\
\hline $\begin{array}{l}\text { Miscellaneous } \\
\text { non-predatory } \\
\text { species }\end{array}$ & $0.08-0.27$ & $0.07-0.09$ & $0.02-0.16$ & $0.07-0.694$ \\
\hline \multicolumn{5}{|l|}{$\begin{array}{l}\text { Predatory } \\
\text { Species }\end{array}$} \\
\hline Tuna spp. & $0.30-0.80$ & 0.30 & $0.06-0.40$ & $0.26-1.15$ \\
\hline Swordfish & $0.80-1.30$ & $1.60^{*}$ & - & $1.20-1.80^{*}$ \\
\hline $\begin{array}{l}\text { Various elasmo- } \\
\text { branch species } \\
\text { (sharks \& rays) }\end{array}$ & 1.00 & $0.70-1.10$ & $0.04-1.50$ & $0.06-2.0$ \\
\hline
\end{tabular}

* based on very limited data 
In Table 1 a summary is given of the regional (Fig. 2) contributions to mercury loads from different land-based sources. From this table it is quite evident that, besides the differences inherent in the contribution of each source category, significant variations in the estimated mercury loads exist between the ten regional sea areas delineated in Fig. 2. The heaviest loads are discharged into the Adriatic Sea and the North Western Basin (regions V \& II in Fig. 2) receiving about one-third and one-quarter of the total load respectively. It is to be noted that these two areas, enriched in mercury loads, are bordered by industrialized countries and receive considerable inputs from major rivers and various coastal effluents. Although Table 1 clearly indicates that rivers are the main land-based source of mercury to all regions (Fig. 2), yet a distinction has to be made between man-made pollution and the background loads carried naturally from areas with mercury anomaly into the sea.

Concentrations of mercury in coastal water, as reported by UNEP (1983a), are illustrated by regions in Table 6. Also mercury content in sediments from different parts, mostly coastal, of the Mediterranean are given in Table 3. As could be expected,

Table 6. Mercury concentrations in coastal waters of the Mediterranean Sea.

\begin{tabular}{|c|c|c|c|}
\hline Region & Area & $\begin{array}{l}\text { Physico-chemical } \\
\text { form }\end{array}$ & $\begin{array}{c}\text { Concentration } \\
\mu \mathrm{g} / \mathrm{l}\end{array}$ \\
\hline \multirow[t]{7}{*}{ II } & Rhone Delta & dissolved & $0.010-0.19$ \\
\hline & Ligurian Coast & total & $0.012-0.26$ \\
\hline & Coasts of Tuscany & & 0.02 \\
\hline & and Rosignano & & 0.18 \\
\hline & $\begin{array}{l}\text { (close to chlur- } \\
\text { alkali plant) }\end{array}$ & & \\
\hline & Cecina & Dissolved & $0.012-0.031$ \\
\hline & & Total & $0.032-0.061$ \\
\hline \multirow[t]{4}{*}{ V } & NW Adriatic & Particulate & $1-7$ \\
\hline & Istrian Coast & Total & 0.04 \\
\hline & Adriatic & Total & 0.07 \\
\hline & Gulf of Trieste & Dissolved & $0.073-0.17$ \\
\hline VIII & $\begin{array}{l}\text { Saronikos Gulf } \\
\text { (close to sewage } \\
\text { outfall) }\end{array}$ & Total & $0.15-0.60$ \\
\hline $\mathrm{X}$ & Israel & $\begin{array}{l}\text { Dissolved } \\
\text { (Labile) }\end{array}$ & $\begin{array}{l}0.06 \\
(0.01-0.18)\end{array}$ \\
\hline \multicolumn{3}{|c|}{ editerranean coast } & $0.02-0.55$ \\
\hline
\end{tabular}

(UNEP, 1983a)

Note: See also Figure 2. 
the values given in both tables $(3 \& 6)$ indicate significant variations not only between the different regions but also within the same region. Although the data in these two tables simply shows that high mercury levels occur in areas where chlor-alkali plants, mines or sewage outfalls are situated (UNEP, 1983a), yet the comparison and interpretation of these values should be done with extremely great care. An example which may clarify this point is the consideration of the data summarized in Table 3 . It is evident that the comparison between the given figures for the different areas only makes sense if the factors upon which mercury concentrations in the sediments were based are taken into account. The most important of these, perhaps, are the mineralogical and lithological characteristics, organic content, grain size distributions and the fraction factor of sediments analysed (Philipps, 1977). Moreover, the application of different leaching-extraction techniques (Table 3) may yield incomparable results (UNEP, 1983a).

Information concerning mercury inputs, levels and characteristics is badly needed, however it is not solely required for the overall assessment of mercury in the marine ecosystem. In addition, attention should be paid to the various "key" processes and factors which characterize the system's nature and its receiving capacity, control mercury levels and transformations, and determine outputs of mercury. It should be pointed out that the consideration of the spatial and temporal variabilities caused by different physical phenomena such as mixing, turbulence, upwelling, transport and dilution processes are of great importance. From another point of view, mercury species are known to be inter-convertible, hence the determination of total concentrations is of rather limited value if the levels of mercury in the different chemical forms are not known. In fact, mercury undergoes modifications in the valence state of the element and is subjected to a variety of transformations as a result of various processes and reactions (resuspension, absorption on particulate matter, sedimentation, oxidationreduction and methylation). Consequently, it should be realized that without quantification of these processes and the rates of the associated changes, the prediction of the behaviour, flow and the fate of mercury in the system seems to be impossible.

In view of the above, it is obvious that the data base available to date in different coastal areas of the Mediterranean Sea is essentially descriptive. Although it is already possible to identify some general features of mercury levels in some compartments of such systems, yet no definitive in-depth investigations have taken place to:

a. quantify the effectiveness of such basins in trapping mercury and its availability for biomethylation and bioaccumulation.

b. determine the amount of mercury transmitted, especially from Mediterranean regions adjacent to known areas with mercury anomalies, to the open water and consequently the significance and contribution of the "hot spots" to the large scale Mediterranean Basin mercury problem.

c. evaluate the discharge rates which would maintain acceptable limits of mercury levels in the Mediterranean.

It is relevant to note that a major constraint on the implementation of the above mentioned vital tasks is the deficiency and/or inadequacy of data.

The acquisition of extensive, reliable baseline environmental data together with quantitative knowledge of mercury inputs, levels, forms and related biogeochemical processes is a necessary prerequisite for modelling mercury cycling in the marine system. For the development of site-specific mass balance models, particularly in hot spots, systematic and coordinated, observational and experimental programmes will 
have to be conducted to feed and test the models. Continuing interaction should be maintained between these programmes and modelling objectives.

\section{Conclusion}

Although the Mediterranean Sea has been subjected to considerable studies through different MED POL Projects, yet the demands for a final assessment of the biogeochemical cycle of mercury are not matched in size by the efforts being expended.

The preceding discussions indicate that we cannot pretend to have complete quantitative knowledge of the behaviour of mercury in either the whole Mediterranean or in some of its parts, especially the "hot spots". To bridge gaps and to generate the required knowledge more quickly a holistic approach, aiming ultimately at establishing a mass balance, for both scales is needed.

Throughout this work the need to pursue genesis research has been repeatedly emphasized and the importance of promoting mass balance models for the biogeochemical cycle of mercury for both the entire Mediterranean Sea and individual coastal basins, locally affected by significant mercury inputs, were abundantly clarified.

\section{ACKNOWLEDGEMENTS}

The support of the UNESCO/UNDP/Alexandria University Aquatic Pollution Project - EGY/73/058 for the present work is gratefully acknowledged.

The author wishes to express his sincere gratitutde to Prof. Y. Halim, principal investigator of this project for providing facilities and valuable suggestions.

\section{REFERENCES}

Arnold, M., Seghaier, A., Martin, D., Buat-Menard P. and Chesselet, R. (1982) Géochimie de l' aérosol marin au-dessus de la Méditerranée Occidentale. VI es Journées Etud. Pollutions. Cannes, C.I.E.S.M., 27.

Bernard, M. (1978) Heavy metals and chlorinated hydrocarbons in the Mediterranean Sea. Ocean Management, 3:253.

Bethoux, J. P. (1980) Mean fluxes across sections in the Mediterranean Sea, evaluated on the basis of waters and salt budgets and of observed salinities. Oceanologica Acta, 3, (1) : 79.

Buat-Menard, P. and Arnold, M. (1978) The heavy metal chemistry of atmospheric particulate matter emitted by Mount Etna Volcano. Geophys. Res. Lett. 5: 245.

Buat-Menard, P. and Chesselet, R. (1979) Variable influence of the atmospheric flux on the trace metal chemistry of oceanic suspended matter. Earth Planet Sci. Lett. 42: 399.

Chesselet, R., Arnold, M. Seghaier, A., Buat-Menard, P. and Decadt, G. (1981) Sources and fluxes of trace mtals over the open Mediterranean Sea. Abstract, IAMAP 3rd Scientific Assembly, 17-28 August 1981, Hambourg, FRG, Symposium ACGP-1, "The role of the oceans in atmospheric chemistry".

Cumont, G., Viallex, C., Lelievre, H. and Boenrieth, P. (1972). Contamination des poissons de me par le mercure. Rev. Int. Oceanogr. Med. 28: 95.

Ferrara, R., Petrosino, A., Maserti, E. and Barghigiani, C. (1982). The biogeochemical cycle of mercury in the Mediterranean. Part 2: Mercury in the atmosphere, aerosol and in rain water of a Northern Tyrrhenian area. Environ. Techn. Lett. 3: 449.

Gavis, J., and Ferguson, J.F. (1972). The cycling of mercury through the environment. Water Research 6: 989. 
Osterberg, C. and Keckes, S. (1977). The state of pollution of the Mediterranean Sea. Ambio 6: 321. Philipps, D.J.H. (1977). The use of biological indicator organisms to monitor trace metal pollution in marine and estuarine environments. A review. Environ. Poll. 13: 281.

Piotrowski, J.K. and Inskip, M.J. (1981). Health effects of methyl mercury. MARC Report 24.

Renzoni, A., Bernard, M., Sara, R. and Stoeppler, M (1978). Comparison between Hg body burden of Thynıus thynnus from the Mediterranean and the Atlantic. IV $\underline{e s}$ Journées Etud. Pollutions, Antalya, C.I.E.S.M. 255.

UNEP (1979). Pollutants from land-based sources in the Mediterranean. Meeting of technical experts «n the draft Protocol for the Protection of the Mediterranean Sea against Pollution from Land-based Sources.

UNEP (1983a). . Issessment of the present state of pollution by mercury in the Mediterranean Sea and proposed control measures. Long-term programme for pollution monitoring and research in the Mediterranean Sea (MED POL-Phase II). UNEP/W.G. 91/5.

UNEP (1983b). Long-term programme for pollution monitoring in the Mediterranean (MED POL Phase II). UNE'' Regional Seas Reports and Studies '28.

UNEP (1984). Pollutants from land-based sources in the Mediterranean. UNEP Regional Seus Reports and Studies 32. 